\title{
A pilot safety-feasibility dietary trial targeting insulin inhibition in ten patients with advanced cancer
}

\author{
Eugene J Fine ${ }^{1 *}$, C Segal-Isaacson ${ }^{1}$, Silvia Herzkopf ${ }^{2}$, Joseph Sparano ${ }^{3}$, Maria Romano ${ }^{2}$, Richard Feinman ${ }^{4}$, \\ Nora Tomuta ${ }^{2}$, Amanda Bontempo ${ }^{2}$ \\ From Metabolism, diet and disease \\ Washington, DC, USA. 29-31 May 2012
}

\section{Background}

Hyperinsulinemia, Diabetes type 2, and obesity have been identified as increased risk factors for a variety of cancers [1]. Conversely, insulin inhibition (INSINH) can plausibly limit cancer growth by demonstrated mechanisms including ketosis [2] and regulation of downstream signaling proteins such as mTOR (inhibition) and AMPK (amplification), already in development as drug targets $[3,4]$. Increased ${ }^{18} \mathrm{~F}$-2-fluoro, 2-deoxyglucose (FDG) uptake on positron emission tomography (PET) scan is characteristic of many aggressive malignancies. We examined safety and feasibility of a four week INSINH diet in patients with advanced PET positive cancers, and compared exit vs. baseline PET scan changes as surrogate measures for tumor response.

\section{Methods}

Eligible patients, referred by faculty or self-referred after locating our trial (e.g. www.clinicaltrials.gov/ NCT00444054), had failed or refused $\geq 2$ standard chemotherapy courses and demonstrated FDG-positive scans on baseline PET. Exclusions included concurrent chemotherapy, end-organ disease, hypoglycemic medications, difficult compliance, or BMI $<20$. A supervised INSINH diet restricting starches and sugars for 28 days, was monitored weekly for macronutrient intake, body weight, serum electrolytes, betahydroxybutyrate concentrations [BHB], [insulin], [IGF 1,2]. An exit four-week PET was obtained for comparison with the baseline scan.

\section{Results}

Ten subjects with diverse cancers completed $>26$ days of INSINH without associated unsafe adverse effects. Mean caloric intake decreased $(35 \pm 6) \%$ vs. predicted requirements despite best efforts to encourage increased food consumption. Weight loss (median 4\%, range 0.0-6.1\%) was not judged a health risk in any subject. Mild, reversible side effects included constipation $(n=2)$, transient fatigue $(n=5)$, and leg cramps $(n=2)$. Among nine patients with rapid pre-trial progressive disease (PD) five demonstrated post-trial SD or partial remission (SD/PR) on PET. SD/PR correlated with three-fold higher ketosis compared to those with continued $\operatorname{PD}(\mathrm{n}=4),(\mathrm{p}<0.02)$, but was uncorrelated with reduced calorie intake $(\mathrm{p}=0.45)$ or weight loss $(\mathrm{p}=0.81)$. Insulin correlated inversely with ketosis $(\mathrm{r}=0.62, \mathrm{p}=0.026)$, but did not correlate with IFG(1 or 2$)$.

\section{Conclusions}

Preliminary pilot data in ten subjects demonstrated that an INSINH diet is safe and feasible in selected patients with advanced cancer. The extent of ketosis, but neither calorie deficit nor weight loss correlated with SD/PR. The small sample size requires cautious interpretation. Further evaluation is needed to explore the relation of insulin inhibition to calorie restriction, as well as a potential therapeutic role of diet adjunctive to metabolic or cytotoxic therapies.

Acknowledgements, research support State University New York Research Foundation The Robert and Veronica Atkins Foundation.

${ }^{1}$ Nuclear Medicine, Albert Einstein College of Medicine, Bronx, NY, USA

Full list of author information is available at the end of the article

(c) 2012 Fine et al; licensee BioMed Central Ltd. This is an Open Access article distributed under the terms of the Creative Commons Attribution License (http://creativecommons.org/licenses/by/2.0), which permits unrestricted use, distribution, and reproduction in any medium, provided the original work is properly cited. 


\section{Author details}

${ }^{1}$ Nuclear Medicine, Albert Einstein College of Medicine, Bronx, NY, USA.

${ }^{2}$ Radiation Oncology, Montefiore Medical Center, Bronx, NY, USA. ${ }^{3}$ Medicine, Montefiore Medical Center, Bronx, NY, USA. ${ }^{4}$ Cell Biology, Downstate Medical Center, Brooklyn, NY, USA.

Published: 1 June 2012

\section{References}

1. Lann D, LeRoith $D$ : The role of endocrine insulin-like growth factor-I and insulin in breast cancer. J Mammary Gland Biol Neoplasia 2008, 13:371-375.

2. Fine EJ, Miller A, Quadros EV, Sequeira JM, Feinman RD: Acetoacetate reduces growth and ATP concentration in cancer cell lines which overexpress uncoupling protein 2. Cancer Cell International 2009, 9:14.

3. Yao JC, Lombard-Bohas C, Baudin E, Kvols LK, Rougier P, Ruszniewski P, et al: Daily oral everolimus activity in patients with metastatic pancreatic neuroendocrine tumors after failure of cytotoxic chemotherapy: a phase II trial. J Clin Oncol 2010, 28:69-76.

4. Luo Z, Zang M, Guo W: AMPK as a metabolic tumor suppressor: control of metabolism and cell growth. Future Oncol 2010, 6:457-470.

doi:10.1186/1753-6561-6-S3-P60

Cite this article as: Fine et al: A pilot safety-feasibility dietary trial targeting insulin inhibition in ten patients with advanced cancer. $B M C$

Proceedings 2012 6(Suppl 3):P60

\section{Submit your next manuscript to BioMed Central} and take full advantage of:

- Convenient online submission

- Thorough peer review

- No space constraints or color figure charges

- Immediate publication on acceptance

- Inclusion in PubMed, CAS, Scopus and Google Scholar

- Research which is freely available for redistribution

Submit your manuscript at www.biomedcentral.com/submit 